\title{
Innovation Policy Learning in Iran's Development Plans
}

\author{
Kiarash Fartash \\ Assistant Professor a, k_fartash@sbu.ac.ir \\ Mahdi Elyasi \\ Associate Professor ${ }^{\text {b }}$, elyasi.atu@gmail.com
}

Amir Ghorbani

Policy Officer c, and Researcher a , amirghorbani1373@yahoo.com

\author{
Ali Asghar Sadabadi \\ Assistant Professor a, a_sadabadi@sbu.ac.ir
}

\begin{abstract}
${ }^{a}$ Institute for Science and Technology Studies, Shahid Beheshti University, Daneshju Blvd, Evin Square, Tehran 1983963113, Iran
${ }^{\mathrm{b}}$ Faculty of Management and Accounting, Allameh Tabataba'i University, Dehkade-ye Olampik, West Hemmat Highway, Tehran, 1489684511, Iran

c Vice-Presidency for Science and Technology, No 20, Ladan alley, North Sheikh Bahayee St., MollaSadra St., Vanak Sq., Tehran 1991745681, Iran
\end{abstract}

\begin{abstract}
A part from "future-shaping" tools (such as forecasting, scenario planning, etc.), many countries also use "backward-looking" approaches to develop longterm strategies for switching to a new economic model. A retrospective assessment of accomplishments and failures (or policy learning, PL) helps one learn lessons and improve the effectiveness of innovation policy. Using the example of Iran, this paper examines the use of PL to assess key initiatives in the field of science, technology, and innovation over the past two decades. Field research allowed the authors to identify the main policy goals, analyze their evolution and

the changes in the perception of previously made decisions by politicians themselves. The active use of technical and conceptual PL indicates relative progress made in adjusting the policy vector. At the same time, partisan policy learning remains common, applied to legitimize the current course, which indicates the insufficient maturity of Iran's political system (as is the case in many other developing countries). It was concluded that to make real progress and increase the effectiveness of innovation policy, technical and conceptual aspects should be applied, while keeping the use of partisan policy learning to a minimum.
\end{abstract}

Keywords: policy learning; challenges; lessons; development strategy; foresight; Republic of Iran; technology and innovation policy

Citation: Fartash K., Elyasi M., Ghorbani A., Sadabadi A.A. (2021) Innovation Policy Learning in Iran's Development Plans. Foresight and STI Governance, 15(3), 81-92. DOI: 10.17323/25002597.2021.3.81.92 


\section{Introduction}

Shaping and implementing science, technology, and innovation policy plays a key role in switching to a new economic model. Various tools are applied to enrich national, corporate, and individual strategies, including retrospective analysis and learning from previous accomplishments and failures (policy learning, PL). History is analyzed in terms of the past choices' impact on future scenarios [Schoemaker, 2020]. PL sheds light on the process of shaping science, technology, and innovation policy, helps its developers and experts understand the context in which strategic decisions were made, learn lessons, grasp the essence of the learning process itself, and change politicians' views on the appropriateness of particular steps.

The theoretical foundations of PL were consistently developed in [Heclo, 1974; Sabatier, 1988; Bennett, Howlett, 1992; May, 1992; Hall, 1993]. Since the 1980s its application was extended from public administration to other areas. Over time PL has become part of a systematic approach to innovation [Klochikhin, 2013] and innovation policy [Biegelbauer, 2016; Borras, 2011; Braun, Benninghoff, 2003; Schwerin, Werker, 2003].

The use of PL for strategic planning in the context of developing economies is not sufficiently covered in the literature [Freeman, 1987; Kim, 1997]. Using the example of Iran, this paper examines this process in relation to the shaping of national science, technology, and innovation policy in 2000-2021.

A retrospective review of Iran's past development plans provides an insight into how and why "looking back" can help one "look forward". Strategic planning in Iran began in the middle of the last century [Bostock, Jones, 2014]. So far 10 national development plans have been consistently adopted: five before the 1979 revolution and five after it. The last four plans, implemented since the early 2000s, included specific science and technology sections. Some of the targets set there, such as increasing the share of gross domestic expenditures on research and development (GERD) in GDP, total factor productivity (TFP), and protecting intellectual property (IP) still remain relevant, while others were transformed into other, new objectives.

\section{Literature Review}

Approaches to learning lessons for use in making strategic decisions are being actively studied in the scope of various research fields such as organizational studies [Argote, 2012], the theory of the firm [Penrose, 1959], evolutionary economics [Nelson, Winter, 1982], and technological capabilities [Salisu, Bakar, 2019]. The concept of PL has expanded from public administration [Sabatier, 1988] to other areas including science, technology, and innovation policy studies [Murrall-Smith,
2011, Biegelbauer, 2016, Sanderson, 2002; McCann, Ward, 2012]. Depending on the context, PL can be collective [Hall, 1993] or individual [Heclo, 1974]. [Hall, 1993] presents a classification of PL types applied to shape economic and innovation policy in the UK. The author identified three types of policy learning. The first one (technical $P L$ ) helps to develop and improve policy tools; the second (conceptual) implies adjusting policy goals and objectives, while the third (social) helps adjust the strategic vector and basic attitudes. Examples of the use of PL in different countries can be found in [Murrall-Smith, 2011; Biegelbauer, 2016].

Lieu [Lieu, 2013] mentions technical PL aimed at improving policy tools and programs and conceptual PL carried out to adjust strategic goals and directions. The main PL mechanisms include systemic study, observation, experimentation, and collaboration. In Austria, a combination of five PL types proved to be highly effective in innovation policy shaping: social, reflexive, partisan, technical, and managerial PL [Biegelbauer, 2016]. The European Commission used PL at the organizational and personal levels to assess the integration of climate policies in member states. Factual policy learning extended the understanding of the situation, constructivist PL revealed changes in norms, values, and beliefs, while experimental PL helped with solving specific problems, gaining experience, and understanding the successes or failures of particular decisions [Rietig, Perkins, 2017].

Unlike other PL types, partisan policy learning does not aim to improve policy [Oliver, Pemberton, 2004] or focus on the long term. Its primary functions are managing the current context and minimizing the risks for the current authorities [May, 1992; Nilsoon, 2005; Baily, Compston, 2010]. A similar approach was used in the 1970s in the UK to promote renewable energy sources (RES). Political declarations have never produced any real results [Murrall-Smith, 2011]. Studies show that in more mature political systems, the demand for technical, conceptual, and social PL increases [Moyson et al., 2017].

\section{Methodology}

In the Iranian context, due to the lack of important tacit information, case studies were seen as the best approach to assessing policy learning's contribution to strategic planning [Yin, 2013]. More important science, technology, and innovation policy areas were identified, the corresponding sections of the economic development plans approved in the last two decades analyzed, and the main PL types, mechanisms, and participants described. The tools used to collect field data included semi-structured interviews, expert publications, development plans, and an analysis of the research and development (R\&D) sphere [Suurs et al., 2009]. Officials, experts, 
Table 1. Policy Learning Types

\begin{tabular}{|c|c|c|c|c|}
\hline $\begin{array}{c}\text { Categories of } \\
\text { Policy Learning }\end{array}$ & Technical & Conceptual & Political & Social \\
\hline $\begin{array}{c}\text { Subject/ content of } \\
\text { learning }\end{array}$ & $\begin{array}{c}\text { Effectiveness } \\
\text { and feasibility of } \\
\text { instruments }\end{array}$ & $\begin{array}{c}\text { Defining problems, goals } \\
\text { and strategies }\end{array}$ & $\begin{array}{c}\text { New strategies for } \\
\text { supporting specific goals }\end{array}$ & $\begin{array}{c}\text { Values, duties, relations and } \\
\text { multiple approaches }\end{array}$ \\
\hline $\begin{array}{c}\text { Examples of } \\
\text { policy learning }\end{array}$ & $\begin{array}{c}\text { Adjustment in } \\
\text { instruments/ } \\
\text { standards }\end{array}$ & $\begin{array}{c}\text { Adjustment of new } \\
\text { problems and past goals }\end{array}$ & $\begin{array}{c}\text { Symbolic (usually not stable) } \\
\text { adjustments over time }\end{array}$ & $\begin{array}{c}\text { Collaboration with stakeholders } \\
\text { and testing new mechanisms of } \\
\text { cooperation }\end{array}$ \\
\hline $\begin{array}{c}\text { Evidence of policy } \\
\text { learning }\end{array}$ & $\begin{array}{c}\text { Referring and } \\
\text { describing } \\
\text { evaluations and } \\
\text { behaviors }\end{array}$ & $\begin{array}{c}\text { New systematic problems, } \\
\text { goals, and descriptions }\end{array}$ & $\begin{array}{c}\text { New tactics in policy } \\
\text { discussions }\end{array}$ & - \\
\hline Source: [Murrall-Smith, 2011]. & & \\
\hline
\end{tabular}

scientists, and practitioners involved in the development, approval, and implementation of the plans were interviewed (Tables 2 and 3). The questions asked during the interviews concerned changes in the development goals and areas, visions of the innovation policy vector, arguments used by supporters and critics of various initiatives, ways to obtain relevant competencies, and key participants in the system. In the case of a contradiction in the respondents' assessments, the most common opinion was taken into account. Sixteen innovation system-related strategic goals were identified in the resulting data array for further study (Box 1).

\section{Implementation of Innovation Policy in the Economic Development Plans}

Iran started the systematic planning of economic development in 1948, before most of its peers at the time (such as China, the Republic of Korea, or India) [Mc Leod, 1964; Baldwin, 1967]. Five economic development plans were consistently put into effect between 1948-1979 (the beginning of the Islamic revolution), but the objectives were fully implemented only in the case of the third (and partly the fourth) plan. The last two plans were focused on industrial development based on technology transfer and import substitution. The implementation of the sixth plan was cut short with the onset of the revolution followed by the war with Iraq. As a consequence, throughout the 1980s support for higher education, science, technology, and innovation was not present on the political agenda. As the situation stabilized, the attitude toward the content of economic plans changed. The promotion of science, technology, and innovation has been renewed since the late 1990s [UNCTAD, 2016]. The agency responsible for drafting the plans (the Planning and Budget Organisation, $\mathrm{PBO}$ ) was restructured. The first two plans drawn up in the new period were focused on developing higher education and coordinating innovation actors' efforts (respondents 2, 11, and 13). New, more ambitious goals have been added to the previously set ones, which reflects insufficient policy learning in the R\&D sphere. Since the 2000s (and the adoption of the third plan), science, technology, and innovation were addressed in a separate section.

\section{Box 1. Innovation Policy Goals Subjected to Policy Learning}

1. Improving local content and public procurement in favor of T\&I development

2. Formulation and implementation of industrial policy

3. Coordination and coherence among STI policy actors

4. STI development policies and systematic approach to innovation policy

5. Enforcing intellectual property rights (IPRs)

6. Commercialization and trading IPRs

7. Expanding international technological collaborations and absorbing foreign T\&I investment

8. Developing intermediaries for T\&I development (such as S\&T parks, incubators, and technology districts)

9. Supporting SMEs, promoting their growth and linkages to large firms

10. Promoting private research and technology (R\&T) funds as well as VC funds

11. Insurance of R\&T activities

12. Supporting demand- and mission-based research and innovation

13. R\&D share of GDP

14. Supporting $R \& D$ activities

15. Supporting the creation of technology-based firms affiliated with universities (university spin-offs)

16. Encouraging the development of high-tech technologies (both generally and thematically) 
Table 2. Respondents Interviewed during the Study

\begin{tabular}{|c|c|c|c|c|c|c|}
\hline \multirow[t]{2}{*}{ № } & \multirow[t]{2}{*}{ Interviewee } & \multirow[t]{2}{*}{ Date } & \multicolumn{4}{|c|}{$\begin{array}{l}\text { Involvement into the } \\
\text { plan preparation }\end{array}$} \\
\hline & & & 3rd & 4th & 5th & 6th \\
\hline 1 & Senior researcher, member of RTTG & $12-03-2016$ & & * & * & \\
\hline 2 & Senior expert at PBO, member of RTTG & 07-03-2017, 12-04-2021 & * & * & * & * \\
\hline 3 & Senior civil servant at VPST \& MIMT & 26-01-2016 & * & * & & \\
\hline 4 & Senior policy consultant, member of RTTG & $15-02-2016$ & & * & * & \\
\hline 5 & Senior civil servant at $\mathrm{PBO}$ & 22-02-2016, 14-04-2021 & * & * & * & * \\
\hline 6 & Former minister & 03-05-2016 & * & * & & \\
\hline 7 & Senior civil servant at VPST & $17-05-2016$ & & & * & \\
\hline 8 & Former vice-minister & $24-05-2016$ & * & * & & \\
\hline 9 & Former vice-president & 05-06-2016 & & * & & \\
\hline 10 & Civil servant and policy expert & 07-06-2016 & & * & * & \\
\hline 11 & Former senior civil servant at $\mathrm{PBO}$ & 15-06-2016, 08-04-2021 & * & * & * & * \\
\hline 12 & Senior policy consultant and expert & 23-06-2016 & * & * & * & \\
\hline 13 & Senior civil servant at $\mathrm{PBO}$ & 29-06-2016 & * & * & & \\
\hline 14 & Policy researcher, faculty member & 22-04-2017, 06-04-2021 & * & * & * & * \\
\hline 15 & Senior civil servant at parliament research center & 09-05-2017, 10-04-2021 & & * & $\star$ & * \\
\hline \multicolumn{7}{|c|}{$\begin{array}{l}\text { Note: The PBO is the lead agency responsible for drafting economic development plans to be approved by the government and parliament. Every five years } \\
\text { the PBO hosts an RTTG meeting; the latter group drafts the science, technology, and innovation sections of the plan over a period of about a year. The RTTG } \\
\text { comprises representatives of MSRT, VPST, MICT, MoD, MoE, MoA, MIMT, and ACECR. Please refer to Table } 3 \text { for explanations of the abbreviations. }\end{array}$} \\
\hline
\end{tabular}

Iran, with its substantial oil and gas reserves, managed to avoid "resource dependence". Over the past decade, industrial production has grown in scale and diversity, so the national economy has become the most diversified among the Middle Eastern countries (the oil and gas sector's share is less than $20 \%$ of GDP) [UNCTAD, 2016; McKinsey, 2016].

Three main stages can be identified in the development of Iran's science, technology and innovation policy [Heshmati, Dibaji, 2019, UNCTAD, 2016].

- In the 1990 s priority was given to transforming and developing higher education infrastructure.

- In the 2000s the focus shifted to promoting R\&D in areas such as bio-, nano-, information, and cognitive technologies.

- In the 2010s the transition to a knowledgebased economy, the commercialization of technologies, and supporting high-tech companies came to the fore [Soofi, Ghazinoory, 2013, Souzanchi, Kashani, 2020].

The main innovation policy areas are presented in Table 4.

Systemic efforts to transform the national economy by promoting the development of science, technology, and innovation have improved statistical indicators. In 2005-2019 significant progress was made in the development of higher education, increas- ing industrial product exports, and upgrading the information and communication technology (ICT) infrastructure. Though the share of GERD in Iran's GDP did not grow during that period, R\&D was actively conducted in new areas including nanoand biotechnology and renewable energy sources. In terms of the number of academic publications, in 2005 Iran was $34^{\text {th }}$ and in 2019 it climbed to $15^{\text {th }}$ place $^{1}$; in terms of the number of papers on nanotechnology it was $4^{\text {th }}{ }^{2}$ The number of patent applications grew from 4,494 in 2005 ( $28^{\text {th }}$ place $)$ to 12,147 in $2019\left(16^{\text {th }}\right) .^{3}$

In 2014-2019 Iran has moved up 59 places in the Global Innovation Index, from $120^{\text {th }}$ to $61^{\text {st }}$ place [Dutta et al., 2020]. The total capacity of power plants operating on renewable energy sources in 2020 amounted to $920 \mathrm{MW}$ (twice as much as in 2017) [Fartash et al., 2021]. The Iranian National Innovation Fund ${ }^{4}$ actively supports high-tech product manufacturers; since 2001 it has financed over 5,870 companies with a total turnover of about 28.5 billion USD in 2020.

\section{Third Economic Development Plan (2000-2004)}

With the adoption of the law on "maximizing the use of domestic capabilities", the development of an R\&D strategy acquired a systemic basis and was described in a separate section of the economic development plan [UNCTAD, 2016]. While previous

\footnotetext{
${ }^{1}$ https://www.scimagojr.com/countryrank.php, accessed on 30.03.2021.

${ }^{2}$ https://statnano.com/report/s29, accessed on 30.03.2021.

${ }^{3}$ https://www3.wipo.int/ipstats/index.htm?tab=patent, accessed on 30.03.2021.

${ }^{4}$ Established in 2001 with initial capital of 3 billion USD. For more see: https://pub.daneshbonyan.ir, accessed on 30.03 .2021
} 
Table 3. List of Organizations Mentioned in Table 2

\begin{tabular}{|l|l|}
\hline \multicolumn{1}{|c|}{ Name } & \multicolumn{1}{c|}{ Acronym } \\
\hline Planning and Budget Organization & PBO \\
\hline Research and Technology Task Group & RTTG \\
\hline Ministry of Science, Research and Technology & MSRT \\
\hline Vice-Presidency for Science and Technology & VPST \\
\hline Ministry of ICT & MICT \\
\hline Ministry of Defense & MoD \\
\hline Ministry of Power & MoP \\
\hline Ministry of Agriculture & MoA \\
\hline Ministry of Industry, Mines and Trade & MIMT \\
\hline $\begin{array}{l}\text { Iranian Academic Center for Education, Culture } \\
\text { and Research }\end{array}$ & ACECR \\
\hline Source: authors. & \\
\hline
\end{tabular}

programs did provide for developing new technologies and competencies, they were not sufficiently consistent and specific. The authors of the law set the goal to promote technological cooperation with foreign companies (respondents 2 and 5). The policy vector pursued in the late 1990s was recognized as a mistake. To better coordinate the work, the Ministry of Culture and Higher Education was transformed into the Ministry of Science, Research, and Technology and was given extended powers (respondents 6, 8, and 11). However, this decision is now also seen as unproductive.

Significant resources were allocated to support private research foundations and companies. Publicly funding half of the costs of demand-driven research by universities was an initiative that counts as a successful one and was renewed in subsequent economic development plans (respondents 4, 11,
13). Universities were allowed to establish hightech companies and own a controlling interest in them. A radical change in the attitude toward promoting $\mathrm{R} \& \mathrm{D}$ development was reducing the role of the state and encouraging the private sector (respondent 2). Given that after the revolution the nationalization of large enterprises and banks was stepped up, this university reform was evidence of active conceptual PL. The third plan was implemented in the context of low oil and gas prices and allowed the country to avoid an economic downturn. Its overall implementation is estimated at about $50 \%$ and the implementation of the $\mathrm{R} \& \mathrm{D}$ related sections was above average (respondents 2 , 5 , and 11).

The fourth, fifth, and sixth plans lacked clear, realistic goals. Their content was a rather chaotic medley of diverse political objectives and tools, including attracting foreign direct investment, promoting the commercialization of $R \& D$ results and international technological cooperation, and the development of the national innovation system as a whole (respondents 1,2, and 11).

\section{Fourth Economic Development Plan (2004-2009)}

Unlike the previous one, the fourth plan was developed in the context of high energy prices. A wide range of poorly coordinated ideas and initiatives were proposed for inclusion, so their harmonious integration into a five-year cycle turned out to be problematic (respondent 9). The key goals and visions looked unrealistic and utopian. At the same time, it was recognized that changing the economy's focus from natural resources to research and knowledge could only be based on increasing TFP

\begin{tabular}{|l|l|l|l|}
\hline \multicolumn{1}{|c|}{ Table 4. Main Innovation Policy Initiatives } \\
\hline \multicolumn{1}{|c|}{ Policy } & \multicolumn{1}{|c|}{$\begin{array}{l}\text { Year of } \\
\text { ratification }\end{array}$} & Ratified by & \multicolumn{1}{c|}{ Objectives } \\
\hline 2025 Vision: 20-year Vision Plan & 2005 & $\begin{array}{l}\text { Supreme } \\
\text { Leader }\end{array}$ & $\begin{array}{l}\text { Providing desired status of Iran, including STI, for a 20 year } \\
\text { period }\end{array}$ \\
\hline $\begin{array}{l}\text { The Law of Registration of Patents, } \\
\text { Industrial Designs, and Trademarks }\end{array}$ & 2007 & Parliament & Protection of intellectual property rights \\
\hline $\begin{array}{l}\text { Law for Supporting Knowledge- } \\
\text { based Firms and Commercializing } \\
\text { Innovations }\end{array}$ & 2010 & Parliament & $\begin{array}{l}\text { Supporting KBFs to facilitate transition to a knowledge-based } \\
\text { economy }\end{array}$ \\
\hline $\begin{array}{l}\text { National Master Plan for Science and } \\
\text { Education }\end{array}$ & 2011 & $\begin{array}{l}\text { Supreme } \\
\text { Council for } \\
\text { the Cultural } \\
\text { Revolution }\end{array}$ & $\begin{array}{l}\text { Presenting objectives, policies, strategies, structures, and } \\
\text { requirements for the development of T\&I until 2025 }\end{array}$ \\
\hline $\begin{array}{l}\text { National Policy for S\&T 2014 and } \\
\text { National Policy for a Resilient } \\
\text { Economy }\end{array}$ & $\begin{array}{l}\text { Supreme } \\
\text { Leader }\end{array}$ & $\begin{array}{l}\text { Providing a holistic framework policy for supporting T\&I } \\
\text { development and industrialization }\end{array}$ \\
\hline $\begin{array}{l}\text { Development plans (containing STI- } \\
\text { related articles) }\end{array}$ & $\begin{array}{l}\text { 6th plan } \\
\text { approved in } \\
2017\end{array}$ & Parliament & $\begin{array}{l}\text { The most comprehensive framework policy of Iran for a five- } \\
\text { national policies, to spearhead the development of Iran in all } \\
\text { aspects including STI }\end{array}$ \\
\hline $\begin{array}{l}\text { Act of Maximum Use of Production } \\
\text { and Services to Satisfy the Country's } \\
\text { Needs and Enhance Them in Exports }\end{array}$ & $\begin{array}{l}\text { 1996, revised } \\
\text { in 2012 \& 2019 }\end{array}$ & $\begin{array}{l}\text { Parliament } \\
\text { Source: authors basing on [Soofi, Ghazinoory, 2013; UNCTAD, 2016; Souzanchi, Kashani, 2020]. }\end{array}$ & $\begin{array}{l}\text { Supporting local content and active role of domestic firms in } \\
\text { international projects to enhance their capability }\end{array}$ \\
\hline
\end{tabular}


through intensive innovation development (respondents 5 and 9). The implementation of the law on maximizing the use of national capabilities remained a priority. Compared to previous plans, the promotion of the "technological" vector and improving the domestic value chains was considerably stepped up, in line with the highly open economic policy at the time. The focus was on promoting the growth of small and medium-sized enterprises (SMEs), strengthening their links with big businesses, developing value chains in industrial clusters, supporting technology parks, and creating special technology zones. The national innovation system's productivity was supposed to be increased through the institutional modernization of the R\&D sphere, including strengthening intellectual property protection, improving research in frastructure, stepping up commercialization, and creating a technology brokers' institution. Support for private foundations and science and technology projects aiming to meet actual demand was expanded.

\section{Fifth Economic Development Plan (2011-2017)}

A local version of the US Bayh-Dole Act (1980) was adopted. Priority was given to an integrated industrial development strategy, strengthening the country's technological potential, and gaining a competitive edge. The focus was on protecting intellectual property and encouraging universities and research organizations to establish private knowledge-intensive start-ups. Note that according to previous plans, such companies could be exclusively owned by universities.

\section{Sixth Economic Development Plan (2017-2021)}

As was the case with the previous plan, the parliament had to overcome the government's reluctance to approve it (respondents 2, 9 and 12). Initially the government committed to fully implementing the economic development plans, but then found a way to get around this obligation (respondents 2 and 12). The provisions of the fifth and sixth plans essentially coincide with the fourth one. They were relatively proactive and endogenous, with the exception that the executive authorities were officially allowed to implement the initiatives specified in the plans selectively. Export promotion and integration into global value chains were brought to the fore, along with public procurement to promote R\&D, support for small and medium-sized businesses, and strengthening their ties with large companies. Continuity has been maintained with the fifth plan regarding intellectual property and research-intensive university start-ups. The sixth plan is mainly focused on promoting $R \& D$ poten tial through international cooperation and attracting foreign direct investment. The effort to engage the private sector in developing high-tech projects was stepped up.

\section{The Use of Policy Learning in Drafting Economic Development Plans}

Key aspects of innovation were identified through a content analysis of the plans, policy documents, drafts, and reports prepared by the Research and Technology Task Group (RTTG). The R\&D-related development goals were identified using two main criteria:

- feasibility of the science, technology, and innovation objectives (assessed mainly on the basis of the comments of the respondents directly involved in drafting the plans, and partly by analyzing the wording of the documents)

- presence in at least two plans.

The goals of the last four plans presented in Tables 5-8 were identified primarily from their approved versions, and the final RTTG report. Table 9 indicates relevant PL types, the participants who conducted it, and the mechanisms applied to adjust the policies.

The fact that policy tools have been modified indicates that technical policy learning took place, while a change in benchmarks suggests the use of conceptual PL. We learned about social and partisan policy learning mainly from the respondents' comments. Changes in the nature of political dialogue on particular issues indicate social PL.

Partisan policy learning was confirmed by policymakers' justifying and maintaining their legitimacy. PL of various types was carried out in relation to the 16 basic policy goals (see Box 1). The only case of social PL was discovered, resulting in a changed attitude toward the knowledge economy and knowledge-intensive companies and the emergence of a common position to provide comprehensive support for them. Six cases of partisan policy learning were established with the objective of strengthening legitimacy by making minor adjustments to strategies. Technical PL was revealed in seven basic areas, leading to the development of improved and diversified policy tools (the exact opposite of partisan PL). The seven cases of conceptual policy learning indicate a willingness to align goals with the requirements of technological and innovative development.

All in all, Iran has not been successful in accomplishing the targets set in the economic development plans (respondents 1, 2, 8, and 11). The fact that these targets were transferred into subsequent plans essentially unchanged indicates an awareness of their relevance and ongoing efforts (albeit unsuccessful) to accomplish them. The frequency of partisan learning indicates attempts to maintain legitimacy by transferring unfulfilled tasks to the next 


\section{Table 5. Status of the Considered Policy Issues in the 3rd Plan (2000-2004)}

\begin{tabular}{|c|c|}
\hline $\begin{array}{l}\text { Policy } \\
\text { issue }\end{array}$ & Status in the 3rd plan \\
\hline 1 & Abiding by MULC law (A5 88); minimum of $10 \%$ share of local content in international contracts (A 89 ) \\
\hline 2 & No direct implication \\
\hline 3 & Establishment of MSRT as the main coordinator among T\&I policy actors (A 99) \\
\hline 4 & No direct implication \\
\hline 5 & Preparing bill of IPR law one year after approval of plan (executive solutions, 15 in S\&T section) \\
\hline 6 & No direct implication \\
\hline 7 & No direct implication \\
\hline 8 & No direct implication \\
\hline 9 & No direct implication \\
\hline 10 & Facilitating establishment of private R\&T funds and supporting them (A 100) \\
\hline 11 & Providing supportive insurance for R\&T development activities of private research organizations (A 101) \\
\hline 12 & $\begin{array}{l}\text { Funding up to } 60 \% \text { of research projects that have demand from a governmental organization and are carried out by universities } \\
\text { and research organizations (A 102) }\end{array}$ \\
\hline 13 & $1.5 \%$ of which two thirds should be funded by government with a $15 \%$ share of basic research (A 102) \\
\hline 14 & Providing the private sector with incentives to increase their engagement in R\&D activities (A 102) \\
\hline 15 & $\begin{array}{l}\text { Authorization of universities to establish governmental R\&T-intensive firms with up to } 49 \% \text { ownership held by university staff } \\
\text { (A 154) }\end{array}$ \\
\hline 16 & Supporting establishment of firms involved in advanced technology development (A 171) \\
\hline
\end{tabular}

\section{Table 6. Status of the Considered Policy Issues in the 4th Plan (2004-2009)}

\begin{tabular}{|c|c|}
\hline \begin{tabular}{c|c} 
Policy \\
issue
\end{tabular} & Status in the 4th plan \\
\hline 1 & $\begin{array}{l}\text { Abiding by MULC law (A 42); abiding MULC in all international contracts (A 13); public procurement directed toward } \\
\text { technology development (A 37) }\end{array}$ \\
\hline 2 & Formulating an industrial policy to improve technological capabilities and spillovers (A 21) \\
\hline 3 & No direct implication \\
\hline 4 & Formulation and implementation of NIS (A 46); formulating a holistic research and technology development system (A 43) \\
\hline 5 & Design and implementation of a comprehensive IPRs system (A 45) \\
\hline 6 & Putting into effect mechanisms for IP valuation and trade (A 45) \\
\hline 7 & $\begin{array}{l}\text { Developing effective international technological collaboration supports and mechanisms (A 46); developing incentives to } \\
\text { encourage foreign investment directed toward T\&I development (A 48) }\end{array}$ \\
\hline 8 & $\begin{array}{l}\text { Developing institutional infrastructures for promoting knowledge-based activities such as S\&T parks and incubators (A 45); } \\
\text { extending incentives provided to free economic zones to firms located in S\&T parks (A 47) }\end{array}$ \\
\hline 9 & $\begin{array}{l}\text { Enhancing linkages between SMEs and big firms (A 39); removing barriers impeding the growth of big firms (A 39); developing } \\
\text { industrial networks and clusters to boost manufacturing (A 39) }\end{array}$ \\
\hline 10 & $\begin{array}{l}\text { Supporting the establishment and growth of private R\&T funds (A 45); support the creation and development of technology } \\
\text { financing mechanisms such as VC funds (A 40) }\end{array}$ \\
\hline 11 & Designing proper mechanisms for insuring T\&I development activities (A 50) \\
\hline 12 & $\begin{array}{l}\text { Funding up to } 60 \% \text { of research projects that have private sector demand and are carried out by universities and research } \\
\text { organizations (A 45); directing R\&D activities toward demand- and mission-based projects (A 46) }\end{array}$ \\
\hline 13 & $2 \%$ funded entirely by the government (A 46); \\
\hline 14 & Providing financial and non-financial incentives to increase the involvement of SMEs in R\&D activities (A 45) \\
\hline 15 & $\begin{array}{l}\text { Authorization of universities to establish governmental R\&T-intensive firms with up to } 49 \% \text { ownership held by university staff } \\
\text { (A 51) }\end{array}$ \\
\hline 16 & $\begin{array}{l}\text { Taking measures to improve domestic absorptive capacity in advanced technologies (A 40); adopt a plan to improve technology } \\
\text { development in areas such biotech; nano, ICT, nuclear, and environment (A 43) }\end{array}$ \\
\hline
\end{tabular}




\section{Table 7. Status of the Considered Policy Issues in the 5th Plan (2010-2015)}

\begin{tabular}{|c|c|}
\hline $\begin{array}{l}\text { Policy } \\
\text { issue }\end{array}$ & Status in the 5th plan \\
\hline 1 & Abiding by MULC law (A 150); priority of public procurement from local firms (A 78); facilitation of local content (A 150) \\
\hline 2 & Formulating an industrial policy supporting enhanced industrial manufacturing and value added (A 150) \\
\hline 3 & Coordination among T\&I policy actors in policymaking and supervision by MSRT and SCSRT6 (A 16) \\
\hline 4 & $\begin{array}{l}\text { Implementation of national master plan for science and education (A 6); formulating an Islamic-Iranian development model } \\
\text { (A 1) }\end{array}$ \\
\hline 5 & Changing IPR evaluation system from declarative to assessment-based (A 17) \\
\hline 6 & $\begin{array}{l}\text { Establishment of IP stock market (A 17); supporting manufacturers to acquire IP (A 17); transferring ownership of IP in } \\
\text { projects funded by government to universities and research organizations (A 17) }\end{array}$ \\
\hline 7 & $\begin{array}{l}\text { Promoting technological international collaboration to acquire know-how and encourage foreign firms to bring some of their } \\
\text { R\&D facilities to Iran (A 17) }\end{array}$ \\
\hline 8 & Supporting the establishment of private S\&T parks \& incubators (A 17) \\
\hline 9 & $\begin{array}{l}\text { Supporting the creation of technological startups (A 17); developing brokers to link SMEs and big firms and facilitate } \\
\text { commercialization by startups and their acquisition by big firms (A } 17 \text { \& 80); improving linkages of SMEs and big firms which } \\
\text { aids in the development of industrial networks, clusters, and local content (A 80) }\end{array}$ \\
\hline 10 & Support VC funds by providing them with managed funds annually (A 151) \\
\hline 11 & No direct implication \\
\hline 12 & $\begin{array}{l}\text { Funding up to } 50 \% \text { of research projects that have demand from a non-governmental organization and are carried out by } \\
\text { universities and research organizations (A 102) }\end{array}$ \\
\hline 13 & $3 \%$ with annual increase of at least $0.5 \%$ (A 16) \\
\hline 14 & Facilitate access of private technology-based firms to research labs and R\&D facilities (A 17) \\
\hline 15 & $\begin{array}{l}\text { Faculty members at universities are authorized to establish R\&T-intensive firms with the approval of university boards of } \\
\text { trustees (A 17) }\end{array}$ \\
\hline 16 & $\begin{array}{l}\text { Leveraging advanced technology development to improve industrial competitiveness and added value (A 150); acquiring } \\
\text { know-how in areas such as petrochemical; biotech, nano, ICT and microelectronics (A } 129 \text { \& 197) }\end{array}$ \\
\hline
\end{tabular}

\section{Table 8. Status of the Considered Policy Issues in the 6th Plan (2016-2021)}

\begin{tabular}{|c|c|}
\hline $\begin{array}{l}\text { Policy } \\
\text { issue }\end{array}$ & Status in the 6th plan \\
\hline 1 & Maximum utilization of local content to strengthen technological learning and capability (A 51) \\
\hline 2 & Enhancing domestic industrial capabilities through entering GVCs (A 4) \\
\hline 3 & No direct implication \\
\hline 4 & Achieving one fourth of national productivity by improving TFP (A4) \\
\hline 5 & Enhancing IPR enforcement at the firm level (A 4) \\
\hline 6 & Supporting research commercialization (A 4) \\
\hline 7 & Leveraging foreign investment and projects managed by MNCs to enhance domestic technological capability (A 4; A 51; A64) \\
\hline 8 & Improving STI diplomacy (A 105) \\
\hline 9 & Supporting the establishment of private technology towns (A 74) \\
\hline 10 & Supporting and empowering knowledge-intensive firms in production and export (A 51) \\
\hline 11 & Establishment of high-tech fund under the MIMT (A 69) \\
\hline 12 & No direct implication \\
\hline 13 & $\begin{array}{l}\text { Funding up to 50\% of research projects that have demand from and are done by universities and research organizations (A 64); } \\
\text { Creation and stimulation of demand for knowledge-intensive products (A 51) }\end{array}$ \\
\hline 14 & $3 \%$ by 2021 \\
\hline 15 & $\begin{array}{l}\text { All governmental organizations and firms should spend at least } 1 \% \text { and } 3 \% \text { of their annual budget and income, respectively, on } \\
\text { R\&D (A 64) }\end{array}$ \\
\hline 16 & Faculty members at universities are authorized to establish private R\&T-intensive firms (A 1) \\
\hline
\end{tabular}




\section{Table 9. Findings on Technology and Innovation Policy Issues and their Associated Policy Learning}

\begin{tabular}{|c|c|c|c|c|}
\hline No. & Policy issue & Type of learning & $\begin{array}{c}\text { Actors } \\
\text { involved }\end{array}$ & $\begin{array}{c}\text { Learning } \\
\text { mechanisms }\end{array}$ \\
\hline 1 & Improving local content and public procurement in favor of T\&I development & TPL; PPL & $\begin{array}{l}\text { CS; PE\&C; } \\
\text { HO }\end{array}$ & $\begin{array}{l}\text { EIPP; DI; } \\
\text { T\&LD }\end{array}$ \\
\hline 2 & Formulation and implementation of industrial policy & TPL; PPL & $\begin{array}{l}\text { CS; PE\&C; } \\
\text { HO }\end{array}$ & T\&LD; DI \\
\hline 3 & Coordination and coherence among STI policy actors & PPL & $\begin{array}{l}\text { CS; HO; } \\
\text { PE\&C; } \\
\text { RTTG }\end{array}$ & $\begin{array}{l}\text { T\&LD; EIPP; } \\
\text { DI }\end{array}$ \\
\hline 4 & STI development policies and systematic approach to innovation policy & SPL; PPL & $\begin{array}{l}\text { CS; HO; } \\
\text { PE\&C; } \\
\text { RTTG }\end{array}$ & T\&LD; DI \\
\hline 5 & Enforcing IPRs & TPL & $\begin{array}{l}\text { RTTG; CS; } \\
\text { PE\&C }\end{array}$ & EIPP; DI \\
\hline 6 & Commercialization and trading IPRs & TPL & $\begin{array}{l}\text { RTTG; CS; } \\
\text { MoA }\end{array}$ & $\begin{array}{l}\text { EIPP; T\&LD; } \\
\text { DI }\end{array}$ \\
\hline 7 & $\begin{array}{l}\text { Expanding international technological collaboration and absorbing foreign T\&I } \\
\text { investment }\end{array}$ & CPL & RTTG; CS & EIPP; T\&LD \\
\hline 8 & $\begin{array}{l}\text { Developing intermediaries for T\&I development (such as S\&T parks, } \\
\text { incubators, and technology districts) }\end{array}$ & CPL & $\begin{array}{l}\text { RTTG; PA; } \\
\text { CS; HO }\end{array}$ & EIPP; T\&LD \\
\hline 9 & Supporting SMEs, promoting their growth and linkages with big firms & TPL; CPL & CS; PE\&C & EIPP; PPE \\
\hline 10 & Promoting private research and technology (R\&T) funds as well as VC funds & TPL; CPL & $\begin{array}{l}\text { RTTG; CS; } \\
\text { PE\&C }\end{array}$ & EIPP; T\&LD \\
\hline 11 & Insurance of R\&T activities & $\mathrm{CPL}$ & RTTG; CS & T\&LD; \\
\hline 12 & Supporting demand- and mission-based research and innovation & CPL & $\begin{array}{l}\text { RTTG; CS; } \\
\text { PE\&C }\end{array}$ & EIPP; \\
\hline 13 & R\&D share of GDP & PPL & RTTG; CS & EIPP; T\&LD \\
\hline 14 & Supporting R\&D activities & PPL & RTTG; CS & EIPP; \\
\hline 15 & $\begin{array}{l}\text { Supporting the creation of technology-based firms affiliated with universities } \\
\text { (university spin-offs) }\end{array}$ & CPL; SPL & $\begin{array}{l}\text { RTTG; PA: } \\
\text { HO: }\end{array}$ & EIPP; DI \\
\hline 16 & $\begin{array}{l}\text { Encouraging the development of high-tech technologies (both generally and } \\
\text { thematically) }\end{array}$ & TPL; & $\begin{array}{l}\text { RTTG: CS; } \\
\text { HO }\end{array}$ & T\&LD; DI \\
\hline \multicolumn{5}{|c|}{$\begin{array}{l}\text { Legend: } \\
\text { TPL: Technical policy learning } \\
\text { CPL: Conceptual policy learning } \\
\text { PPL: Political policy learning } \\
\text { SPL: Social policy learning } \\
\text { RTTG, MoA - see description at Table } 3 \\
\text { CS: Civil servants at member organizations in RTTG } \\
\text { PE\&C: Policy experts and wider policy communities including media, academics, consultants, and policy entrepreneurs } \\
\text { PA: Public authorities beyond government including judiciary, parliament, and public organizations } \\
\text { HO: High level officials at least at vice-ministerial level } \\
\text { T\&LD: Systemic practical and academic training as well as lesson drawing from other countries } \\
\text { PPE: Previous related policy experience } \\
\text { EIPP: Evaluation and implementation of previous plans } \\
\text { DI: Discussions and interactions among policy actors. }\end{array}$} \\
\hline
\end{tabular}

plans intact or in an even more ambitious format. This issue is typical for developing countries and without dealing with it, achieving tangible science, technology, and innovation policy results would be impossible [Compston, 2010, Casady, Parra, 2020].

\section{Discussion}

Now we will discuss the similarities and differences between our results and the practices described in the literature as well as their applicability to other developing countries. Iran's situation is similar to the one described in [May, 1992]: policymakers do not see the pragmatic adjustment of policy goals and tools as a priority, but focus on strengthening their own legitimacy through rhetoric and declarations of commitment to the set goals [Murrall-Smith, 2011]. A similar situation is also observed in certain African coun- tries which also update their national development plans every few years. Despite the declared goals to increase the share of GERD in GDP, sufficient funds to promote $\mathrm{R} \& \mathrm{D}$ are not actually allocated, while relevant official statistics are not published [Siyanbola et al., 2016; Oladeji, Adegboye, 2019].

In contrast to partisan PL, social policy learning is much less common in Iran. Our study revealed its application in relation to only two policy goals, which is again typical for other countries. For example, in Lebanon the government has implemented at least five science, technology, and innovation development plans, but the situation remains largely unchanged [Gaillard, 2010].

Nevertheless, positive changes have also been noted in Iran. Over the past five years the dialogue on the relevance of creating innovations domestically 
has been strengthening and is being taken very seriously; concerns about the transition to a new economic model are growing. These issues are discussed by the general public and taken into account through social policy learning.

Since 2010 the attention paid to science, technology, and innovation has grown significantly. After the lifting of the sanctions imposed on Iran in 2016, the government introduced special requirements for the "technology section" of the plans, including the requirement to conduct $R \& D$ in the scope of all international contracts. An example of a systemic approach is encouraging the innovation-based development of universities. Technical and conceptual policy learning were applied more often than other types (seven times each). Technical PL did not imply changing policy goals but helped to improve the tools for their implementation. There are known examples of its application in shaping innovation policy in $\mathrm{Ma}$ laysia, Singapore [Lim, 2018, Narayanan, Yew-Wah, 2018], and other countries [Smits, Kuhlmann, 2004; Boekholt, 2010]. Conceptual policy learning changes policy vision, its scope, and target groups. Priority was given to international cooperation, providing support for R\&D projects in various forms, linking them to actual demand, and focusing on accomplishing the set goals. Over the past two decades, this type of policy learning has led to a shift in political emphasis from research to technology development, and in the past six years, to innovation (including the abandonment of a linear approach to creating innovations in favor of building an innovation system). The focus on increasing supply is giving way to initiatives to promote demand. There were important changes in approaches to supporting commercialization, attracting foreign investment, and encouraging international partnerships in the R\&D sphere. Conceptual PL has also been actively applied in Indonesia and the Philippines [Damuri et al., 2018; Quimba et al., 2018]. PL was most actively carried out by the RTTG and officials at different levels. A similar situation was observed in Thailand, where the National Science, Technology, and Innovation Committee (NSTIC) and the National Research Council (NRC) made key contributions to the development of innovation policy [UNCTAD, 2015].

The role of experts is increasing: they participated in PL for eight of the 16 objectives under consideration. As to the PL mechanisms, the most common ones are learning from past experience and evaluating the implementation of previous plans (applied in 11 and 12 cases, respectively). This means that R\&D policy in Iran is increasingly shaped using a scientific, evidence-based approach. Given the growing involvement in PL of various kinds of actors, primarily experts, establishing a dialogue between them is becoming increasingly important.

\section{Conclusion}

This paper presents a case study of the practical application of PL in shaping Iran's science, technology, and innovation policy. Based on the survey results and strategy analysis, different policy learning types and mechanisms have been identified. The findings can be useful for shaping appropriate policies in other countries, primarily developing ones.

1. To accomplish real shifts and increase the effectiveness of innovation policy, technical, conceptual, and social PL should be used, while keeping the use of partisan PL to a minimum. This would be possible only if a wide range of stakeholders are involved in policy shaping, with a sufficiently deep dialogue between them. The economic effect will be achieved if innovation development is consistent with other policy areas (educational, industrial, policies and so on).

2. Pragmatic short- and medium-term goals should be set, for example, to increase businesses' contribution to $\mathrm{R} \& \mathrm{D}$ by introducing relevant incentives.

3. PL procedures should be improved upon by experimenting with the innovation system in line with evidence-based principles. Not only formal quantitative indicators should be taken into account (e.g., the export of new products), but also its contribution to economic growth [Albert et al., 2013]. Policy evaluation allows one to determine whether the goals and the tools applied to achieve them were adequate [Dawkins, Colebatch, 2006]. Regular foresight studies can provide informational context, describing the mainstream and emerging technology landscape.

4. Previous results must be evaluated prior to developing new strategies; a limited number of basic issues should be identified to focus on.

5. The importance of emerging windows of opportunity for the R\&D sphere should be demonstrated to the government in a sufficiently clear way [Lee, 2005]. Gaining political support for making use of such windows will help build up the technological potential in the short or medium term already.

6. An efficient transition to the knowledge economy would not be possible without the involvement of politicians. To form such a commitment, the potential contribution of R\&D to accomplishing various economic, social, and environmental objectives should be demonstrated [Mazzucato, 2021].

Other important factors contributing to the increased maturity and stability of the innovation system are introducing effective mechanisms to protect domestic high-technology markets, promoting demand for relevant products, and involving businesses in policy-making and the creation of development institutions. 


\section{References}

Albert N., Link N., Vonortas N. (2013) Handbook on the Theory and Practice of Program valuation, Cheltenham: Edward Elgar Pub.

Argote L. (2012) Organizational learning: Creating, retaining and transferring knowledge, Berlin: Springer Science \& Business Media Pub.

Bailey I., Compston H. (2010) Geography and the politics of climate policy. Geography Compass, 8(4), 1097-1114. http://dx.doi. org/10.1111/j.1749-8198.2010.00366.x

Baldwin G.B. (1967) Planning and development in Iran, Baltimore: Johns Hopkins Press.

Bennett C.J., Howlett M. (1992) The lessons of learning: Reconciling theories of policy learning and policy change. Policy Sciences, 25(3), 275-294. http://dx.doi.org/10.1007/BF00138786

Biegelbauer P. (2016) How different forms of policy learning influence each other: Case studies from Austrian innovation policymaking. Policy Studies, 37(2), 129-146. http://dx.doi.org/10.1080/01442872.2015.1118027

Boekholt P. (2010) The Evolution of Innovation Paradigms and their Influence on Research, Technological Development and Innovation Policy Instruments. In: The Theory and Practice of Innovation Policy (eds. R.E. Smits, S. Kuhlmann, P. Shapira), Cheltenham: Edward Elgar Pub., pp. 333-362.

Borrás S. (2011) Policy learning and organizational capacities in innovation policies. Science and Public Policy, 38(9), 725-734. http://dx.doi.org/10.3152/030234211X13070021633323

Bostock F., Jones G. (2014) Planning and Power in Iran: Ebtehaj and Economic Development Under the Shah, London: Routledge Pub.

Braun D., Benninghoff M. (2003) Policy learning in Swiss research policy - The case of the National Centres of Competence in Research. Research Policy, 32(10), 1849-1863. http://dx.doi.org/10.1016/S0048-7333(03)00063-5

Casady C.B., Parra J.D. (2020) Structural Impediments to Policy Learning: Lessons from Colombia’s Road Concession Programs. International Journal of Public Administration, 44(5), 359-371. http://dx.doi.org/10.1080/01900692.2020.1724142

Damuri Y., Aswicahyono H., Christian D. (2018) Innovation Policy in Indonesia. In: Innovation Policy in ASEAN (ed. M. Ambashi), Jakarta: Economic Research Institute for ASEAN and East Asia, pp. 96-127. https://www.eria.org/uploads/media/5. ERIA_Innovation_Policy_ASEAN_Chapter_4.pdf, accessed 18.06.2021

Dawkins J., Colebatch H.K. (2006) Governing through Institutionalized Networks: The Governance of Sydney Harbour. Land Use Policy, 23 (3), 333-343. http://dx.doi.org/10.1016/j.landusepol.2004.09.006

Dunlop C.A. (2017) Pathologies of policy learning: What are they and how do they contribute to policy failure? Policy and Politics, 45(1), 19-37. http://dx.doi.org/10.1332/030557316X14780920269183

Dunlop C.A., Radaelli C.M. (2013) Systematizing policy learning: From monolith to dimensions. Political Studies, 61: 599-619. http://dx.doi.org/10.1111/j.1467-9248.2012.00982.x

Dutta S., Lanvin B., Wunsch-Vincent S. (2020) The Global Innovation Index 2020: Who Will Finance Innovation?, Ithaca, Fontainebleau, Geneva: WIPO. https://www.wipo.int/edocs/pubdocs/en/wipo_pub_gii_2020.pdf, accessed 15.07.2021.

Fartash K., Khayatian M., Ghorbani A., Sadabadi A. (2021) Interpretive Structural Analysis of Interrelationships of the Sustainable Development Goals (SDGs) in Iran. International Journal of Sustainable Development and Planning, 16(1), 155-163. http://dx.doi.org/10.18280/ijsdp.160116

Fiorino D. (2001) Environmental policy as learning: A new view of an old landscape. Public Administration Review, 61(3), 322334. http://dx.doi.org/10.1111/0033-3352.00033

Freeman C. (1987) Technology policy and economic policy: Lessons from Japan, London: Frances Pinter.

Gaillard J. (2010) Science and Technology in Lebanon: A University-driven Activity. Science, Technology and Society, 15(2), 271-307. http://dx.doi.org/10.1177\%2F097172181001500205

Hall P.A. (1993) Policy Paradigms, Social Learning and the State: The Case of Economic Policymaking in Britain. Comparative Politics, 25 (3), 275-296. http://dx.doi.org/10.2307/422246

Heclo H. (1974) Modern Social Politics in Britain and Sweden, New Haven CT: Yale University Press.

Heshmati A., Dibaji S.M. (2019) Science, Technology, and Innovation Status in Iran: Main Challenges. Science, Technology and Society, 24(3), 545-578. http://dx.doi.org/10.1177/0971721819873192

Johnson B.H. (2010) Institutional learning. In: National systems of innovation: Toward a theory of innovation and interactive learning (ed. B.Å. Lundvall), London: Anthem Press, pp. 23-46.

Kim L. (1997) Imitation to innovation: The dynamics of Korea's technological learning, Cambridge, MA: Harvard Business Press.

Klochikhin E.A. (2013) Innovation system in transition: Opportunities for policy learning between China and Russia. Science and Public Policy, 40 (5), 657-673. http://dx.doi.org/10.1093/scipol/sct021

Lee K. (2005) Making a Technological Catch-up: Barriers and opportunities. Asian Journal of Technology Innovation, 13(2), 97131. http://dx.doi.org/10.1080/19761597.2005.9668610

Lieu J. (2013) Influences of policy learning, transfer, and post transfer learning in the development of China's wind power policies, Brighton: University of Sussex.

Lim H. (2018) Innovation Policy in Singapore. In: Innovation Policy in ASEAN (ed. M. Ambashi), Jakarta: Economic Research Institute for ASEAN and East Asia, pp. 198-217. https://www.eria.org/uploads/media/8.ERIA_Innovation_Policy_ASEAN_ Chapter_7.pdf, accessed 12.06.2021.

May P.J.(1992) Policy Learning and Failure. Journal of Public Policy, 12 (4),331-354. http://dx.doi.org/10.1017/S0143814X00005602

Mazzucato M. (2021) Mission Economy: A Moonshot Guide to Changing Capitalism, Dutton: Penguin Pub. 
McCann E., Ward K. (2012) Policy assemblages, mobilities and mutations: Toward a multidisciplinary conversation. Political Studies Review, 10(3), 325-332. http://dx.doi.org/10.1111/j.1478-9302.2012.00276.x

McKinsey \& Company (2016) Iran: A trillion-dollar opportunity?, New York: McKinsey Global Institute. https://en.inif.ir/documents/40462/302234/2016.pdf/8e6dafac-e6c8-5800-b6c4-b3f967c3a953?t=1577084952000, accessed 08.04.2021.

McLeod T.H. (1964) National Planning in Iran: A report based on the experiences of the Harvard Advisory Group in Iran, Cambridge, MA: Harvard Advisory Group.

Moyson S., Scholten P., Weible C.M. (2017) Policy learning and policy change: Theorizing their relations from different perspectives. Policy and Society, 36(2), 161-177. http://dx.doi.org/10.1080/14494035.2017.1331879

Murrall-Smith S. (2011) Policy learning and the development of renewable energy policy in the United Kingdom, Plymouth: University of Plymouth.

Narayanan H., Yew-Wah L. (2018) Innovation Policy in Malaysia. In: Innovation Policy in ASEAN (ed. M. Ambashi), Jakarta: Economic Research Institute for ASEAN and East Asia, pp. 128-162. https://www.eria.org/uploads/media/6.ERIA_Innovation_Policy_ASEAN_Chapter_5.pdf, accessed 04.11.2020.

Nelson R.R., Winter S.G. (1982) An evolutionary theory of economic change, Cambridge, MA: Harvard Business Press.

Nilsson M. (2005) Learning, frames, and environmental policy integration: The case of Swedish energy policy. Environment and Planning C: Government and Policy, 23(2), 207-226. http://dx.doi.org/10.1068/c0405j

Oladeji S.I., Adegboye A.A. (2019) Science and Technology Policy for Nigeria's Development Planning. Journal of Education, Society and Behavioural Science, 32(4), 1-12. http://dx.doi.org/10.9734/jesbs/2019/v32i430182

Oliver M.P., Pemberton H. (2004) Learning and change in 20th century British economic policy. Governance, 17, 415-441. http:// dx.doi.org/10.1111/j.0952-1895.2004.00252.x

Penrose E.T. (1959) The Theory of the Growth of the Firm, Oxford: Oxford University Press.

Quimba F.M., Albert J.R., Llanto G.M. (2018) Innovation Policy in Philippines. In: Innovation Policy in ASEAN (ed. M. Ambashi), Jakarta: Economic Research Institute for ASEAN and East Asia, pp. 163-197. https://www.eria.org/uploads/media/7.ERIA_Innovation_Policy_ASEAN_Chapter_6.pdf, accessed 17.03.2021.

Rietig K., Perkins R. (2017) Does learning matter for policy outcomes? The case of integrating climate finance into the EU budget. Journal of European Public Policy, 25(4), 487-505. http://dx.doi.org/10.1080/13501763.2016.1270345

Rongping M., Zhongbao R., Sida Y., Yan Q. (2008) Technology foresight towards 2020 in China: The practice and its impacts. Technology Analysis \& Strategic Management, 20(3), 287-307. http://dx.doi.org/10.1080/09537320801999587

Sabatier P.A. (1988) An Advocacy Coalition Framework of Policy Change and the Role of Policy-Oriented Learning Therein. Policy Sciences, 21: 129-168. http://dx.doi.org/10.1007/BF00136406

Salisu Y., Bakar L. (2019) Technological capability, relational capability and firms' performance the role of learning capability. Revista de Gestão, 27(1), 79-99. http://dx.doi.org/10.1108/REGE-03-2019-0040

Sanderson I. (2002). Evaluation, Policy Learning and Evidence-Based Policy Making, Public Administration, 80 (1), 1-22. http:// dx.doi.org/10.1111/1467-9299.00292

Schoemaker P.J.H. (2020) How historical analysis can enrich scenario planning. Futures and Foresight Science, 2(3-4), e35. https:// doi.org/10.1002/ffo 2.35

Schwerin J., Werker C. (2003) Learning innovation policy based on historical experience. Structural Change and Economic Dynamics, 14(4), 385-404. http://dx.doi.org/10.1016/S0954-349X(03)00031-6

Sharabaroff A., Stuggins G., Semikolenova Y. (2013) Energy Efficiency: Lessons Learned from Success Stories, Washington: World Bank Publications.

Siyanbola W., Adeyeye A., Olaopa O., Hassan O. (2016) Science, technology and innovation indicators in policy-making: The Nigerian experience. Palgrave Communications, 2, 16015. http://dx.doi.org/10.1057/palcomms.2016.15

Smits R., Kuhlmann S. (2004) The rise of systemic instruments in innovation policy. International Journal of Foresight and Innovation Policy, 1(1-2), 4-32. http://dx.doi.org/10.1504/IJFIP.2004.004621

Soofi A., Ghazinoory S. (2013) Science and Innovations in Iran: Development, Progress, and Challenges, London: Palgrave Macmillan Pub.

Souzanchi Kashani E. (2020) Linking institutions and technical changes in a developing context: Historical evidence from Iran. Innovation and Development, 10(3), 347-371. http://dx.doi.org/10.1080/2157930X.2019.1647614

Suurs R., Hekkert M., Kieboom S., Smits R. (2010) Understanding the formative stage of technological innovation system development: The case of natural gas as an automotive fuel. Energy Policy, 38, 419-431. http://dx.doi.org/10.1016/j.enpol.2009.09.032

UNCTAD (2015) Science, Technology and Innovation Policy Review of Thailand, Geneva: United Nations Conference on Trade and Development. https://unctad.org/system/files/official-document/dtlstict2015d1_en.pdf, accessed 16.07.2021

UNCTAD (2016) Science, Technology and Innovation Policy Review of the Islamic Republic of Iran, Geneva: United Nations Conference on Trade and Development. https://unctad.org/system/files/official-document/dtlstict20163_en.pdf, accessed 16.07.2021

UNESCO (2008) Science, Technology \& Innovation Policy for Lebanon: Comprehensive Document, Paris: The United Nations Educational, Scientific and Cultural Organization. http://www.unesco.org/new/fileadmin/MULTIMEDIA/HQ/SC/pdf/sc_sti_ lebanon_en.pdf, accessed 12.02.2021.

Yin R.K. (2013) Case study research: Design and methods, California: Sage Pub.

Yongabo P., Göransson B. (2020) Constructing the national innovation system in Rwanda: Efforts and challenges. Innovation and Development, http://dx.doi.org/10.1080/2157930X.2020.1846886

Zhang Y., Marsh D. (2016) Learning by doing: The case of administrative policy transfer in China. Policy Studies, 37(1), 35-52. http://dx.doi.org/10.1080/01442872.2015.1107959 